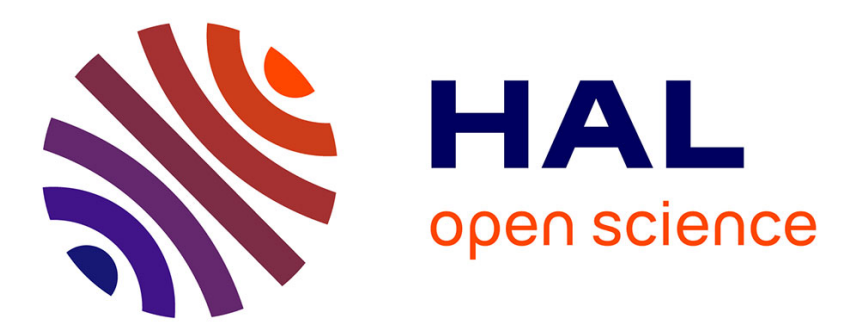

\title{
Cytochrome P4501A mRNA and protein induction in striped bass (Morone saxatilis)
}

Eric D. H. Durieux, Richard Connon, Inge Werner, Leandro d'Abronzo, Patrick S Fitzgerald, Jimmy L Spearow, David J Ostrach

\section{To cite this version:}

Eric D. H. Durieux, Richard Connon, Inge Werner, Leandro d'Abronzo, Patrick S Fitzgerald, et al.. Cytochrome P4501A mRNA and protein induction in striped bass (Morone saxatilis). Fish Physiology and Biochemistry, 2012, 38, pp.1107-1116. 10.1007/s10695-011-9597-6 . hal-00789805

\section{HAL Id: hal-00789805 https://hal.science/hal-00789805}

Submitted on 19 Feb 2013

HAL is a multi-disciplinary open access archive for the deposit and dissemination of scientific research documents, whether they are published or not. The documents may come from teaching and research institutions in France or abroad, or from public or private research centers.
L'archive ouverte pluridisciplinaire HAL, est destinée au dépôt et à la diffusion de documents scientifiques de niveau recherche, publiés ou non, émanant des établissements d'enseignement et de recherche français ou étrangers, des laboratoires publics ou privés. 


\section{Cytochrome P4501A mRNA and protein induction in the striped bass}

\section{2 (Morone saxatilis)}

4 Eric D.H. Durieux ${ }^{1,3, *}$, Richard E. Connon ${ }^{2}$, Inge Werner ${ }^{2,4}$, Leandro S. D’Abronzo ${ }^{2,5}$, Patrick S.

$5 \quad$ Fitzgerald $^{1}$, Jimmy L. Spearow ${ }^{1,6}$ and David J. Ostrach ${ }^{1,7}$.

6

$7{ }^{1}$ Pathobiology, Conservation \& Population Biology Laboratory, John Muir Institute of the

8 Environment, Center for Watershed Sciences, University of California, Davis, One Shields

9 Avenue, Davis, CA 95616, USA.

$10{ }^{2}$ Aquatic Toxicology Laboratory, School of Veterinary Medicine, Department of Anatomy,

11 Physiology and Cell Biology, University of California, Davis, California 95616, USA.

$12 *$ Eric D.H. Durieux (corresponding author): durieux@univ-corse.fr

13 Current addresses:

$14{ }^{3}$ Eric D.H. Durieux: UMR 6134 Sciences Pour l'Environnement, Université de Corse Pasquale

15 Paoli, BP 52, 20250 Corte, France

$16{ }^{4}$ Inge Werner: Swiss Centre for Applied Ecotoxicology, Eawag/EPFL, Überlandstrasse 133, 8600

17 Dübendorf, Switzerland

$18{ }^{5}$ Leandro D’Abronzo: University of California Medical Center, 10535 Hospital Way, Mather, CA

1995616, United States.

$20{ }^{6}$ Jimmy Spearow: Department of Toxic Substances Control, 8800 Cal Center Drive, Sacramento,

21 CA, 95826, United States.

$22{ }^{7}$ David Ostrach: Ostrach Consulting, 18671 County Road 96 Woodland, CA 95695, United States. 


\section{Abstract}

25 The striped bass (Morone saxatilis) support a valuable recreational fishery, and are among the most

26 important piscivorous fish of the San Francisco Estuary. This species has suffered a significant

27 decline in numbers over the past decades and there is indication that contaminants are important

28 contributors. Polycyclic Aromatic Hydrocarbons (PAHs) and Polyhalogenated aromatic

29 hydrocarbons (PHAHs) including PCBs and dioxins are widespread in the Estuary, they typically

30 bioaccumulate through trophic levels, reaching highest levels in top predators, and are known to

31 affect fish health and development. The aim of this study was to investigate the dynamics of

32 cytochrome P4501A (Cypla) induction simultaneously at different levels of biological

33 organization (RNA transcription and protein synthesis) as a biomarker of exposure to PAHs and

34 PHAHs. We utilized $\beta$-naphthoflavone (BNF) as a model PAH to induce Cypla responses in

35 juvenile striped bass in both dose-response, and time-response assessments and determined Cypla

36 mRNA and protein levels. Significant responses were measured in both systems at $10 \mathrm{mg} \mathrm{BNF. \textrm {Kg } ^ { - }}$

37 , a concentration used for time-response studies. Messenger RNA levels peaked at $6 \mathrm{~h}$ post-

38 injection, while protein levels increased progressively with time, significantly peaking at $96 \mathrm{~h}$ post-

39 injection; both remaining elevated throughout the duration of the test ( 8 days). Our data suggest

40 that rapid induction of gene transcription following exposure and subsequent cumulative protein

41 synthesis could provide a useful means of identifying temporal variants in exposure to Cypla

42 inducers in Morone saxatilis. The potential application of this combined Cypla gene and protein

43 biomarker in this species for field studies is discussed.

45 Keywords: Cypla, biomarker, fish, Morone saxatilis, "beta-naphthoflavone", "Polycyclic

46 Aromatic Hydrocarbon" 


\section{Introduction}

49 The San Francisco Estuary is subject to diverse anthropogenic pressures, including the release of

50 numerous contaminants that have greatly altered the functioning of this ecosystem (Bennett and

51 Moyle 1996; Sommer et al. 2007; Strange 2008). Among contaminants, polycyclic aromatic

52 hydrocarbons (PAHs) and polyhalogenated aromatic hydrocarbons (PHAHs) including

53 polychlorinated biphenyls (PCBs) and dioxins are widespread in the Estuary (Davis et al. 2007;

54 Oros et al. 2007). These chemicals generally occur as complex mixtures originating from a variety

55 of sources: storm water runoff, wastewater treatment plant effluent, atmospheric deposition and

56 dredged material disposal. PAHs and especially PHAHs typically bioaccumulate through the food

57 web, reaching highest levels in top predators (Hylland 2006; Beyer and Biziuk 2009). In fish, water

58 or food exposure to PAHs and PHAHs has been reported to result in numerous biological effects,

59 such as weight loss, immunotoxicity, hepatotoxicity, cardiotoxicity, edema formation, genotoxicity

60 and tumor promotion (e.g. Tanguay et al. 2005; Reynaud and Deschaux 2006, Pinkney et al. 2010;

61 Nahrgang et al. 2010; Wills et al. 2010; Hiken et al. 2011). Such compounds are known to affect

62 early life stages development, i.e. malformations of embryo and larvae (Barron et al. 2004;

63 Sundberg et al. 2006, Billiard et al. 2008) and cause alteration of endocrine system function and

64 reproduction (Monosson 1999/2000). These deleterious effects may reduce survival leading to

65 population level effects.

67 The striped bass (Morone saxatilis) were introduced from the East Coast of USA in the late 1880s, 68 now support a valuable recreational fishery, and are among the most important piscivorous fish in

69 the San Francisco Estuary. Along with a number of other pelagic fish species in the estuary, this

70 species has suffered a significant decline in numbers (Bennett and Moyle 1996; Feyrer et al. 2007). 
71 Extensive research on this and other pelagic fish species have also indicated that invasive species,

72 food limitation, intra- and inter-specific competition and predation, increased entrainment, habitat

73 losses, disease and impaired offspring (Ostrach et al. 2008; Sommer et al. 2007) likely contribute

74 to population declines, and there is indication that contaminants are important contributors

75 (Stevens et al. 1985; Bailey et al. 1994; Bennett et al. 1995; Ostrach et al. 2008). Monitoring and

76 assessment of the striped bass population in the San Francisco Estuary has been extensive over the

77 past 50 years for various reasons. Striped bass exploit the entire estuary ecosystem including the

78 rivers, Delta region, outer bays and nearshore Pacific Ocean (Stevens et al. 1985, Sommer et al.

79 2007). Striped bass are an apex predator in the system and as such are important sentinels for this

80 ecosystem (Ostrach et al. 2009). The majority of fish species declining in the San Francisco

81 Estuary are listed as either threatened or endangered and cannot be studied in the laboratory due to

82 their status as well as the difficulty of handling and lack of appropriate methods for

83 experimentation. Unlike these other species, striped bass are not a listed species and are amenable

84 to breeding and experimentation in captivity (Ostrach et al. 2008).

86 To understand the effect of contaminants on fish we must use systems that measure the extent of

87 sublethal biological effects resulting from chemical exposure. Molecular and biochemical

88 biomarkers, in particular, are valuable tools for monitoring contaminant exposure (Tom and

89 Austlander 2005; Sarkar et al. 2006; Fedorenkova et al. 2010), however, most require validation

90 for better interpretation of field data (e.g. Connon et al. 2010). Toxic responses are directly linked

91 to a contaminant's mode of action, and are generally preceded by modifications in gene

92 transcription. RNA is not the final product of a gene, as the gene function is carried out by the

93 resulting protein. The level of protein may be regulated through transcriptional, post- 
94 transcriptional, and post-translational mechanisms. Thus measurements of mRNA transcription

95 may or may not be indicative of subsequent protein levels and activity.

97 Induction of cytochrome P4501A (Cypla) is a powerful biomarker of exposure to PAHs and

98 PHAHs (i.e. PCBs and dioxins) and has been used for biomonitoring assessments in a number of

99 aquatic organisms (Anderson et al. 1994; Stegeman and Hahn 1994; van der Oost et al. 2003;

100 Hylland 2006). Cytochrome P4501A is a monooxygenase involved in xenobiotic biotransformation

101 and detoxification of many PAHs, PCBs and dioxins, and is induced by the binding of these

102 compounds with Aryl hydrocarbon receptor (AhR), i.e. a cytosolic ligand-activated transcription

103 (Stegeman and Hahn 1994; Hahn 2001). The induction of Cypla may then be regulated at various

104 post-transcriptional steps (Abdelhamid et al. 2010; Amara et al. 2010). Cytochrome P4501A can

105 also be activated by other pathways and plays a strong role in steroid hormone biosynthesis,

106 tryptophan and retinol metabolism (review in Monostory et al. 2009). Induction of Cypla varies

107 between fish species (Wirgin et al. 1996, Willet et al. 1997, Oris and Roberts 2007), so that a

108 specific evaluation needs to be performed before using this biomarker on a sentinel species in

109 environmental monitoring programs. In this study we thus focus on both Cypla gene expression

110 and protein content in order to provide a combined biomarker specific for the striped bass Morone

111 saxatilis.

112

113 The aims of this study are two-fold, investigating the dynamics of Cypla induction at different

114 biological levels of organization (RNA transcription and protein synthesis), and to explore the

115 relationship between the measured parameters. By conducting sublethal exposure response studies

116 that integrate molecular and biochemical assessments, we are better able to understand the

117 relationship between gene expression and effects at higher levels of biological organization. In the 
118 present study, we utilize the PAH model, $\beta$-naphthoflavone (BNF), to induce Cypla responses in

119 juvenile striped bass in both i) dose response and ii) time response experiments, in order to identify

120 and utilize transcriptional and translational differences as measures of temporal variants of

121 xenobiotic exposure.

122

123 2. Methods

124 2.1. Fish handling: One-year old striped bass juveniles (fork length: $19.9 \pm 2.5 \mathrm{~cm}$; body mass:

$125114 \pm 40 \mathrm{~g}$ ) used in this study were produced from a domestic brood stock maintained at the Center

126 for Aquatic Biology and Aquaculture at UC Davis. Fish were moved to the experimental facility

127 two days prior to the start of the experiment. They were maintained in aerated circular (diameter:

$12860 \mathrm{~cm}$; height: $35 \mathrm{~cm}$ ) flow-through freshwater tanks (10 fish per tank) at $19-20^{\circ} \mathrm{C}$ water

129 temperature and under natural photoperiod. Fish were fed daily at $2.5 \%$ body weight with \#3

130 Crumbled Salmon/Trout chow (Silver Cup, Murray, UT 84157), but were fasted for $24 \mathrm{~h}$ prior to

131 test initiation to avoid any post-anesthesia risk (e.g. regurgitation of food and/or fecal

132 contamination of recuperation water)

133 2.2. BNF exposures and sample preparation: Fish were exposed to BNF through intra-peritoneal

134 injections in two experiments: (i) a 24h dose response to BNF concentrations (Sigma-Aldrich

135 Corporation) of $0.1,1,10$, and $25 \mathrm{mg} \mathrm{kg}^{-1}$, and (ii) a time response study, commencing at time $0 \mathrm{~h}$

136 with either a $10.0 \mathrm{mg} \beta$-naphtoflavone. $\mathrm{kg}^{-1}$ or solvent control (SC), followed by a metabolic

137 detoxification time of $6 \mathrm{~h}, 12 \mathrm{~h}, 24 \mathrm{~h}, 2 \mathrm{~d}, 4 \mathrm{~d}$ and $8 \mathrm{~d}$. Each group of fish $(\mathrm{N}=10)$ for both dose and

138 time response was placed in an individual circular tank (see above). Corn oil (Sunny Select, Super

139 store industries, Lathrop, CA 95330) was used for BNF dilution and as solvent control. Fish 
140 sampled at time zero received no injection. Prior to injection, fish were anesthetized with MS-222

141 (tricaine methanesulfonate, Sigma, St. Louis, MO, USA) at $100 \mathrm{mg} . \mathrm{L}^{-1}$. Upon termination of the

142 experiment, fish were euthanized using an overdose of MS-222, their livers dissected and

143 immediately snap frozen in liquid nitrogen. Liver tissue was then ground in liquid nitrogen to a

144 fine powder using mortar and pestle, aliquots were placed into two separate microcentrifuge tubes,

145 to ensure a homogeneous sample, and stored at $-80^{\circ} \mathrm{C}$ for subsequent molecular and biochemical

146 analyzes.

\section{2.3. Cypla Transcription assessment:}

$148 \quad$ RNA extraction and cDNA synthesis: Total RNA was extracted from powdered liver tissue using

149 RNeasy Mini Kit (Qiagen Inc., Valencia, CA), with on-column DNAse digestion, as per

150 manufactures protocol. Samples were quantified using a NanoDrop spectrophotometer and their

151 quality verified by electrophoresis on $1 \%$ agarose gel. Complementary DNA (cDNA) was

152 synthesized using 100 units of SuperScript III (Invitrogen, Carlsbad, CA, USA), 600 ng random

153 hexadeoxyribonucleotide (pd(N)6) primers (random hexamer primer), 10U RNaseOut (RNase

154 inhibitor), and 1mM dNTPs (all Invitrogen, Carlsbad, CA, USA).

155 Quantitative PCR: We measured Cypla gene (precisely CYP1A1) expression in striped bass using

156 specific probes and primers designed for quantitative PCR (qPCR), as detailed in Table 1. TaqMan

157 Universal PCR Mastermix (Applied Biosystems) was used in cDNA amplifications using an

158 automated fluorometer (ABI PRISM 7900 Sequence Detection System, Applied Biosystems).

159 Quantitative PCR data was analyzed using the relative quantification 2(-Delta Delta CT) method

160 (Livak and Schmittgen, 2001), using $\beta$-actin expression as a reference to which Cypla expression

161 was normalized. Statistical assessments were conducted on $\log _{2}$ normalized data (see below). 
163 2.4. Cypla Protein quantification: A Cypla competitive-ELISA for striped bass was developed

164 following Tom et al. (2002). A brief method description is provided below.

165 2.4.1. Cypla protein production: A strain of Escherichia coli that contained an antigenic fragment

166 of Lithognathus mormyrus Cypla gene was obtained from Dr. Moshe Tom, Israel Oceanographic

167 and Limnological Research, Haifa, Israel. Colonies were grown over night in Lysogeny Broth

168 medium with $100 \mu \mathrm{g} / \mathrm{mL}$ ampicillin at $37^{\circ} \mathrm{C}$ to produce a starter culture. This was used to

169 inoculate one liter of Terrific Broth medium with $50 \mu \mathrm{g} / \mathrm{mL}$ ampicillin and $1.0 \mathrm{mM}$ thiamine at 37

$170{ }^{\circ} \mathrm{C}$. Four hours later heme precursor $\delta$-aminolevulinic acid and isopropyl $\beta$-D-1-

171 thiogalactopyranoside (IPTG) inducer were added to a final concentration of $0.5 \mathrm{mM}$, and the

172 culture was incubated at $28^{\circ} \mathrm{C}$ for 24 hours. After centrifugation at 5,000 x g for 15 minutes in

$173250 \mathrm{ml}$ flasks, bacteria were transferred into $50 \mathrm{~mL}$ centrifuge tubes and spun again. Cells were

174 resuspended into $30 \mathrm{~mL}$ of $0.1 \mathrm{M}$ potassium phosphate buffer, $20 \%$ glycerol, $0.1 \mathrm{mM}$

175 Dithiothreitol (DTT) and 0.1 mM Ethylene Diamine Tetraacetic Acid (EDTA) (pH 7.4). Egg white

176 lysozyme $(0.5 \mathrm{mg} / \mathrm{ml})$ was added to the buffer and incubated for one hour at $4{ }^{\circ} \mathrm{C}$. A $1 / 10,000$

177 dilution of nonselective protease inhibitor (Sigma P8340) and $1 \mu \mathrm{g} / \mathrm{ml}$ DNAase I were added. The

178 resulting spheroplast suspension was then sonicated with a high powered probe sonicator at 25

179 Watts, 8 times for 30 seconds on ice and then centrifuged at 30,000 x g for 2 hours. The Cypla

180 containing cytosol was saved and the pellet was discarded.

181 2.4.2. Cypla protein purification: The Cypla containing cytosol was purified on a Ni+

182 Nitrilotriacetic acid Agarose (Qiagen) column equilibrated with running buffer $50 \mathrm{mM}$ potassium

183 phosphate buffer containing $0.2 \mathrm{M} \mathrm{NaCl}, 20 \mathrm{mM}$ glycine, 20\% glycerol, $0.1 \mathrm{mM}$ EDTA and 0.1 
mM DTT. The poly-His tail that was added on the recombinant protein fragment has a high affinity

185 for the $\mathrm{Ni}+$ ion and allows for the crude extract to pass through and enrich the solution with the

186 protein of interest. The protein was eluted from the column with running buffer containing $50 \mathrm{mM}$

187 histidine. Fractions were analyzed for total protein with the BioRad DC protein assay, and further

188 analyzed with Sodium Dodecyl Sulfate (SDS) polyacrylamide gel (Invitrogen NuPAGE) to

189 determine the fractions containing high concentrations of Cypla. These fractions were pooled, and

190 analyzed with the BioRad DC protein assay to determine total protein content and by SDS gel

191 electrophoresis to determine the Cypla protein concentration. SDS gels showed a prominent band

192 at 55kDa matching the molecular weight of the Cypla protein fragment with a concentration of

$193 \quad 0.18 \mu \mathrm{g} / \mu \mathrm{L}$ in the resulting stock.

2.4.3. Cypla competitive-ELISA optimization and measurement: For the competitive-ELISA, we used the monoclonal mouse anti-fish Cypla antibody (C10-7, Biosense Laboratories) that has been

197 shown to cross-react with a variety of fish species including rainbow trout (Oncorhynchus mykiss),

198 Atlantic salmon (Salmo salar), carp (Cyprinus carpio), turbot (Scophthalmus maximus) and

199 Atlantic cod (Gadus morhua). The produced Cypla protein fraction was coated on high binding 96

200 well plates (Costar 3925, Black) at 100 or $200 \mathrm{ng} / \mathrm{mL}$ Cypla protein fragment in 0.05 M Sodium

201 Bicarbonate, $\mathrm{pH}$ 9.6. Plates were then blocked with PBS buffer $\mathrm{pH} 7.5$ containing $1 \%$

202 Hammerstein Casein and 1.0 mM EDTA. Plates were then co-incubated with increasing

203 concentrations of Cypla protein fragment with 1/5,000 or 1/10,000 diluted Mouse anti-fish Cypla

204 antibody in PBS buffer pH 7.5 containing 1\% Hammerstein Casein, 1.0 mM EDTA, and 0.05\%

205 Tween 20, and then rinsed with PBS and 0.05\% Tween 20. Following incubation with 1/10,000

206 diluted Goat Anti Mouse Horse Radish Peroxidase (HRP) conjugate (Jackson Immuno Research)

207 and rinsing with PBS and 0.05\% Tween 20, HRP substrate ( $35.4 \mu \mathrm{M}$ ADHP (Anaspec, Inc.), 1.76 
mM Urea Hydrogen Peroxide in 0.05 M Sodium Phosphate buffer, pH 7.4) was added. After

209 approximately 30 minutes, fluorescence was measured at $544 \mathrm{~nm}$ excitation with $590 \mathrm{~nm}$ emission

210 on a Wallac Victor 2 Fluorescence Plate Reader. The results confirmed that the antigenic Cypla

211 protein fragment was present. The competitive Cypla ELISA described above was shown to be

212 optimized by coating plates overnight with $200 \mathrm{ng} / \mathrm{ml}$ Cypla at $4^{\circ} \mathrm{C}$, co-incubating S9 fraction

213 sample with 1/10,000 dilution of Mouse anti-fish Cypla in the competitive binding step, and

214 incubating with 1/10,000 dilution of Goat anti Mouse-HRP (Ostrach et al., 2009; Spearow et al., 215 2011).

217 S9 fraction sample was prepared: powdered liver tissues of each sample was homogenized in 10

218 volumes by weight of ice-cold extraction buffer consisting 0.02M 4-(2-hydroxyethyl)piperazine-1-

219 ethanesulfonic acid (HEPES) 0.15M KCl, (pH 7.5) 0.22mM 4-(2-aminoethyl) benzenesulfonyl

220 fluoride and 1/200 protease inhibitor cocktail (Sigma). After centrifugation at 10,000 g for 15

221 minutes at 4C, the S9 supernatant fractions of Morone saxatilis liver samples were obtained for

222 Cypla protein measurement through competitive-ELISA as mentioned above.

224 2.5. Statistical Analyses: Data-sets were not normally distributed; therefore assessments were

225 tested for significance using non-parametric tests. Time responses were assessed using Kruskall-

226 Wallis analysis of variance, with Siegel-Castellan post-hoc multiple correction tests. Differences

227 between data-points and respective solvent controls were assessed using Mann Whitney U tests.

228 Dose response data were compared to controls using Mann Whitney U tests. Analyses were

229 performed using the R software (R Development Core Team, 2008). 


\section{Results}

\section{3.1. Dose Response to BNF exposure:}

233 Striped bass hepatic Cyp la mRNA and protein responses to BNF exposure were dose dependent at $23424 \mathrm{~h}$ post injection (Fig. 1), with both q-PCR and competitive ELISA results correlating positively 235 with increased BNF exposure ( $\mathrm{p}<0.001)$. Cypla mRNA abundance was significantly increased

2363.83 -fold by $1 \mathrm{mg} \beta$-naphthoflavone. $\mathrm{Kg}^{-1}$ relative to solvent controls $(p<0.05)$, and almost 13 -fold 237 by $10.0 \mathrm{mg} \beta$-naphthoflavone. $\mathrm{Kg}^{-1}(\mathrm{p}<0.05)$. Cypla Protein content was significantly upregulated 238 by $10 \mathrm{mg} \beta$-naphthoflavone. $\mathrm{Kg}^{-1} ;(p<0.01)$.

\subsection{Timed Response to BNF exposure:}

240 There was a significant time-dependent response in hepatic Cypla mRNA abundance and protein 241 content in juvenile striped bass exposed to $10.0 \mathrm{mg} \beta$-naphthoflavone. $\mathrm{Kg}^{-1}$ (Fig. 2). Cypla mRNA 242 abundance peaked at $6 \mathrm{~h}$ with a 40.80 fold-increase relative to time zero $(p<0.001)$, then decreased 243 with metabolic detoxification time to $8 \mathrm{~d}$, though remaining significantly up-regulated at $12 \mathrm{~h}, 24 \mathrm{~h}$ 244 and $48 \mathrm{~h}$ relative to time zero $(p<0.01)$. The quantity of Cypla protein, however, increased with

245 time, being significantly higher relative to time zero from $48 \mathrm{~h}$ onwards $(p<0.001)$, peaking at $96 \mathrm{~h}$

246 post-injection $\left(9.3 \mu \mathrm{g} \cdot \mathrm{mg}^{-1}\right.$ total protein $)$ and remained elevated at $8 \mathrm{~d}$ post-injection $\left(6.33 \mu \mathrm{g} \cdot \mathrm{mg}^{-1}\right.$

247 total protein). We note that control fish (SC) also show some increase in mRNA and especially 248 protein levels during the first 24 hours after the beginning of the experiment, which may be due to 249 the effects of handling stress. However, Cypla mRNA and protein levels were significantly higher 250 with respect to solvent controls throughout the $6 \mathrm{~h}$ to $8 \mathrm{~d}$ post-injection period (Fig. 2). 


\section{Discussion}

253 The cytochrome P4501A is considered an excellent indicator of PAHs and PHAHs exposure, with

254 a number of reviews highlighting its use in monitoring (Anderson et al. 1994; Stegeman and Hahn

255 1994; van der Oost et al. 2003; Hylland 2006). Liver microsomal 7 ethoxyresorufin-O-deethylase

256 (EROD) activity is commonly used as a proxy of Cypla induction. Although Cypla is the main

257 enzyme catalyzing the de-ethylation of ethoxyresorufin, other CYP enzymes also can contribute to

258 EROD activity (Spearow et al. 2011). It has also repeatedly been reported that EROD can

259 substantially be inhibited by elevated levels of PCBs, fluoranthene (a prevalent PAH), dioxins and

260 heavy metals (e.g., Viarengo et al. 1997; Gooch et al. 1989; Willett et al. 2001; Ortiz-Delgado et al.

261 2008). EROD activity is technically easy to measure and it is still considered as a robust biomarker

262 (Oris and Roberts 2007) however, this enzymatic activity biomarker shows some limitations that

263 can make interpretation sometimes difficult in field studies (Spearow et al. 2011). Although,

264 several studies have focused separately on Cypla induction at different organizational levels: gene

265 expression (e.g. Rees 2003; Chung-Davidson 2004; Aluru 2008) and protein content or EROD

266 activity (e.g. Gravato and Santos 2002; Miller et al. 2004; Ortiz-Delgado et al. 2008), relatively

267 few have compared gene expression and protein level (see: Kloepper-Sams and Stegeman 1989;

268 Hahn and Stegeman 1994). In this study we focus on both Cypla induction through gene

269 expression and protein content with state of the art techniques in order to provide a combined

270 biomarker applicable for Morone saxatilis. Molecular and biochemical biomarkers are promising

271 tools to assess the effects of chemicals on exposed organisms; however, data interpretation is

272 sometimes the limiting factor hindering their use. Nevertheless, through assessing the combined

273 responses at different levels of biological organization, it is possible to gather more extensive 
274 information towards a more reliable interpretation of data, thus substantiating the use of

275 biomarkers in monitoring efforts. Although, ongoing validation is required in order to apply these

276 biomarkers in field situations, the current study strongly supports the use of Cypla in striped bass

277 as a monitoring tool of sublethal exposure, particularly when two or more assessment methods can

278 be applied synchronously.

279

280 This study has been successful in refining and validating a Cypla protein assay technique for

281 striped bass developed by Ostrach et al. (2009), based on methods by Tom et al. (2002). Results

282 were comparable to responses reported by Kloepper-Sams and Stegeman in Fundulus heteroclitus

283 (1989; 1994), though the newly developed approach, and current techniques permit the

284 presentation of these responses in a more specific manner for Morone saxatilis. The present study

285 applied a competitive-ELISA technique that uses a recombinant Cypla and that allows for a

286 higher-throughput quantitative evaluation of fish Cypla (Tom et al. 2002), than the semi-

287 quantitative western blot method used in the reference study by Kloepper-Sams and Stegeman

288 (1989). In the present study, hepatic Cypla mRNA abundance in juvenile striped bass responded

289 rapidly to BNF exposure peaking within six hours post-exposure. The corresponding

290 biotransformation and detoxification protein was induced progressively peaking at four days post-

291 exposure and remaining elevated throughout the duration of the experiment. Thus the rapid

292 increase in mRNA abundance and subsequent cumulative protein synthesis can provide a useful

293 mean of identifying temporal variants in exposure, where mRNA levels are used to detect recent

294 exposures and protein levels are indicative of past exposures. The time course of Cypla induction

295 may also vary following single or continuous exposure (e.g. Levine and Oris 1999) and to different

296 kind of contaminants; for instance poorly metabolizable AhR inducers such as PCBs or dioxins

297 show prolonged induction even at gene expression level (e.g. Hahn and Stegeman 1994). In field 
298 conditions, chronic exposure is the common environmental situation and fluctuations in pollution

299 levels occur. Time course of biomarker are important in evaluating changes in exposure due to

300 pollution sources or prevention actions. Therefore further studies are evidently required with

301 different modes of exposure and using different Cypla substrates, inhibitors and mixtures before

302 application to field conditions. The difference between these conditions would therefore need to be

303 established based on statistical differences in expression from negative control samples, or

304 previously determined basal expression levels (Tom and Auslander 2005). Nevertheless models

305 that make use of the shorter half life of Cypla mRNA, relative to that of Cypla protein, could

306 potentially detect temporal variants in exposure. This is likely to hold true, not only for Cypla, but

307 for a number of other biomarkers of toxicant exposure and effect.

309 Increasing the informative power of biomarkers, by measuring multiple levels of organization

310 along with establishing suites of biomarkers, indicative of exposure and effect of multiple groups

311 of chemicals, will allow a more comprehensive evaluation of contaminant impacts in exposed

312 organisms. This is especially needed for field monitoring. Current monitoring efforts in the San

313 Francisco Estuary have highlighted the presence of a number of contaminants, including PAHs and

314 PHAHs (SFEI 2008). The newly developed Cypla ELISA described here, along with knowledge

315 based applications of numerous other molecular and biochemical biomarkers, and numerous other

316 molecular and biochemical biomarkers (Burge et al. 2004; Geist et al. 2007; Picha et al. 2008;

317 Washburn et al. 1996; Durieux et al. 2010; Spearow et al. 2011) will permit the assessment and

318 understanding of the sublethal effects of complex mixture of chemical contaminants on striped

319 bass. In addition, as an apex predator, striped bass is a sentinel species in this threatened ecosystem

320 such that the approach developed and described here can be an extremely useful and effective

321 mean of assessing, understanding and potentially mitigating sublethal contamination in estuarine 
322 habitats where striped bass reside. These promising results show the need for continuing research

323 towards establishing links between cellular responses to toxic contaminants with effects on growth,

324 development, behavior, reproduction and survival.

325

326 Acknowledgements

328 Funding for this study was provided by the Interagency Ecological Program on Pelagic Organism

329 Decline Investigations, Department of Water Resources, Sacramento, California, contract Numbers

3304600004664 to D. Ostrach, and 4600004445 to I. Werner, with special thanks to Ted Sommer and

331 Fred Feyrer. We thank Dr. Moshe Tom for providing his modified bacteria, advice and

332 encouragement. This study was part of E.D.H. Durieux's post-doctorate in ecotoxicology at UC

333 Davis in the laboratory of and mentored by D.J. Ostrach. We thank members of the Aquatic

334 Toxicology Laboratory, and Center for Aquatic Biology and Aquaculture; University of California,

335 Davis, for assistance and use of facilities. The opinions expressed in this paper are the authors and

336 do not represent the opinions or policies of the California EPA or Department of Toxic Substances

337 Control.

338 


\section{References}

340 Abdelhamid G, Anwar-Mohamed A, Badary OA, Moustafa AA, El-Kadi AO (2010)

341 Transcriptional and posttranscriptional regulation of CYP1A1 by vanadium in human

342 hepatoma HepG2 cells. Cell Biol Toxicol 26:421-34

343 Aluru N, Vijayan MM (2008) Brain transcriptomics in response to [beta]-naphthoflavone treatment

344 in rainbow trout: The role of aryl hydrocarbon receptor signaling. Aquat Toxicol 87:1-12

345 Amara IE, Anwar-Mohamed A, El-Kadi AO (2010) Mercury modulates the CYP1A1 at

346 transcriptional and posttranslational levels in human hepatoma HepG2 cells. Toxicol Lett

$347 \quad 199: 225-33$

348 Anderson S, Sadinski W, Shugart L, Brussard P, Depledge M, Ford T, et al. (1994) Genetic and Molecular Ecotoxicology: A Research Framework. Environ Health Persp 102:3-8

Bailey HC, Alexander C, Digiorgio C, Miller M, Doroshov SI, Hinton DE (1994) The effect of agricultural discharge on striped bass (Morone saxatilis) in California's Sacramento-San Joaquin drainage. Ecotoxicology 3:123-142

Barron MG, Carls MG, Heintz R, Rice SD 2004. Evaluation of fish early life-stage toxicity models of chronic embryonic exposures to complex polycyclic aromatic hydrocarbon mixtures. Toxicol Sci 78: 60-67

Bennett W, Moyle P (1996) Where have all the fishes gone? Interactive factors producing fish declines in the Sacramento-San Joaquin Estuary. In: Holligaugh J, editor. San Francisco Bay: the ecosystem. Pacific Division of the American Association for the Advancement of Science, San Francisco, pp. 479-518 
362 Beyer A, Biziuk M (2009) Environmental fate and global distribution of polychlorinated biphenyls. Rev Environ Contam Toxicol 201:137-58

Billiard SM, Meyer JN, Wassenberg DM, Hodson PV, Di Giulio RT (2008) Nonadditive effects of

PAHs on Early Vertebrate Development: mechanisms and implications for risk assessment. Toxicol Sci 105:5-23

Burge EJ, Gauthier DT, Van Veld PA (2004) In vitro response of the striped bass natural

Connon RE, Beggel S, D'Abronzo LS, Geist JP, Pfeiff J, Loguinov AV, et al. (2010) Linking

Chung-Davidson Y-W, Rees CB, Wu H, Yun S-S, Li W (2004) \{beta\}-naphthoflavone induction exposure. Comp Biochem Physiol C Toxicol Pharmacol 138:391-400 resistance-associated macrophage protein, Nramp, to LPS and Mycobacterium marinum of CYP1A in brain of juvenile lake trout (Salvelinus namaycush Walbaum). J Exp Biol 207:1533-1542

\section{(207:1533-1542} exposures on the endangered delta smelt (Hypomesus transpacificus). Environ Toxicol Chem 30:1-11

Davis JA, Hetzel F, Oram JJ, McKee LJ. (2007) Polychlorinated biphenyls (PCBs) in San Francisco Bay. Environ Res 105:67-86

Durieux EDH, Farver TB, Fitzgerald PS, Eder KJ, Ostrach DJ (2011) Natural factors to consider when using acetylcholinesterase activity as neurotoxicity biomarker in Young-Of-Year striped bass (Morone saxatilis). Fish Physiol Biochem 37:21-29 44:4328-4333 
Feyrer F, Nobriga ML, Sommer TR (2007) Multidecadal trends for three declining fish species: habitat patterns and mechanisms in the San Francisco Estuary, California, USA. Can J Fish Aquat Sci 64:723-734

Geist J, Werner I, Eder KJ, Leutenegger CM (2007) Comparisons of tissue-specific transcription of stress response genes with whole animal endpoints of adverse effect in striped bass (Morone saxatilis) following treatment with copper and esfenvalerate. Aquat Toxicol 85:28-39

Gooch JW, Elskus AA, Kloepper-Sams PJ, Hahn ME, Stegeman JJ (1989) Effects of ortho- and non-ortho-substituted polychlorinated biphenyl congeners on the hepatic monooxygenase system in scup (Stenostomus chrysops). Toxicol Appl Pharmacol 98:422-433

Gravato C, Santos MA (2002) Juvenile Sea Bass Liver P450, EROD Induction, and Erythrocytic Genotoxic Responses to PAH and PAH-like Compounds. Ecotoxicol Environ Saf 51:115127

Hahn M, Stegeman JJ (1994) Regulation of cytochrome P4501A1 in Teleosts: sustained induction of CYP1A1 mRNA, protein and catalytic activity by 2, 3, 7, 8-Tetrachlorodibenzofuran in the marine fish Stenotomus chrysops. Toxicol Appl Pharmacol 127:187-198

Hahn ME (2001) Dioxin toxicology and the aryl hydrocarbon receptor: insights from fish and other non-traditional models. Mar Biotechnol 3:224-238

Hicken CE, Linbo TL, Baldwin DH et al. (2011) Sublethal exposure to crude oil during embryonic development alters cardiac morphology and reduces aerobic capacity in adult fish. Proc Nat Acad Sci USA 108:7086-7090 
Kloepper-Sams PJ, Stegeman JJ (1989) The temporal relationships between P450E protein content, catalytic activity, and mRNA levels in the teleost Fundulus heteroclitus following treatment with beta-naphthoflavone. Arch Biochem Biophys 268:525-35

411 Kloepper-Sams PJ, Stegeman JJ (1994) Turnover of hepatic microsomal cytochrome P4501A protein and heme in beta-naphthoflavone-induced Fundulus heteroclitus. Mol Mar Biol Biotechnol 3:171-83

414 Levine SL, Oris JT (1999) CYP1A expression in liver and gill of rainbow trout following waterborne exposure: implications for biomarker determination. Aquat Toxicol 46:279-287

416 Livak KJ, Schmittgen TD (2001) Analysis of relative gene expression data using real-time quantitative PCR and the 2(-Delta Delta C(T)) Method. Methods 25:402-8

418 Miller KA, Addison RF, Bandiera SM (2004) Hepatic CYP1A levels and EROD activity in 419 English sole: biomonitoring of marine contaminants in Vancouver Harbour. Mar Environ Res 57:37-54

421 Monostory K, Pascussi J-M, Kóbori L, Dvorak Z (2009) Hormonal regulation of CYP1A 422 expression. Drug Metab Rev 41: 547-572

423 Monosson E (1999/2000) Reproductive and developmental effects of PCBs in fish: a summary of 424 laboratory and field studies. Rev Toxicol 3: 25-75

425 Nahrgang J, Camus L, Carls MG, Gonzalez P, Jönsson M, Taban IC, et al. (2010) Biomarker 426 responses in polar cod (Boreogadus saida) exposed to the water soluble fraction of crude oil. Aquat Toxicol 97:234-242

428 Oris JT, Roberts AP (2007) Statistical analysis of cytochrome P4501A biomarker measurements in 429 fish. Environ Toxicol Chem 26:1742-1750 
430 Oros DR, Ross JR, Spies RB, Mumley T (2007) Polycyclic aromatic hydrocarbon (PAH)

431 contamination in San Francisco Bay: a 10-year retrospective of monitoring in an urbanized

432 estuary. Environ Res 105:101-18

433 Ortiz-Delgado JB, Behrens A, Segner H, Sarasquete C (2008) Tissue-specific induction of EROD

434 activity and CYP1A protein in Sparus aurata exposed to B(a)P and TCDD. Ecotoxicol

$435 \quad$ Environ Saf 69:80-88

436 Ostrach DJ, Low-Marchelli JM, Eder KJ, Whiteman SJ, Zinkl JG (2008) Maternal transfer of xenobiotics and effects on larval striped bass in the San Francisco Estuary. Proc Natl Acad Sci U S A 105:19354-19359

Ostrach DJ, Groff JM, Weber PK, et al. (2009) The Role of Contaminants, within the Context of Multiple Stressors, in the Collapse of the Striped Bass Population in the San Francisco Estuary andits Watershed). Final Year 2 Report for DWR Agreement No. 4600004664. pp

Picha ME, Turano MJ, Tipsmark CK, Borski RJ. (2008) Regulation of endocrine and paracrine sources of Igfs and Gh receptor during compensatory growth in hybrid striped bass (Morone chrysops x Morone saxatilis). J Endocrinol 199:81-94

448 Pinkney AE, Harshbarger JC, Karouna-Renier NK, Jenko K, Balk L, Skarphéðinsdóttir H, Liewenborg B, Rutter MA (2011) Tumor prevalence and biomarkers of genotoxicity in brown bullhead (Ameiurus nebulosus) in Chesapeake Bay tributaries. Sci Tot Environ 410:248-257

452 R Development Core Team (2008) R: A language and environment for statistical computing. R 453 Foundation for Statistical Computing, Vienna, Austria 
Rees CB, McCormick SD, Vanden Heuvel JP, Li W (2003) Quantitative PCR analysis of CYP1A induction in Atlantic salmon (Salmo salar). Aquat Toxicol 62:67-78

456 Reynaud S, Deschaux P (2006) The effects of polycyclic aromatic hydrocarbons on the immune system of fish: A review. Aquat Toxicol 77:229-238

Sarkar A, Ray D, Shrivastava A, Sarker S (2006) Molecular Biomarkers: Their significance and application in marine pollution monitoring. Ecotoxicology 15:333-340

SFEI (2008) The pulse of the estuary: monitoring and managing water quality in the San Francisco Estuary, San Francisco Estuary Institute Annual report: 92pp

Sommer T, Armor C, Baxter R, Breuer R, Brown L, Chotkowski M, et al. (2007) The collapse of 463 pelagic fishes in the upper san francisco estuary. Fisheries 32:270-277

Spearow JL, Kota RS, Ostrach DJ (2011) Environmental contaminant effects on juvenile striped

Stegeman JJ, Hahn ME (1994) Biochemistry and molecular biology of monooxygenases: current perspectives on forms, functions, and regulation of cytochrome P450 in aquatic species. In: Malins DC, Ostrander GK, editors. Aquatic Toxicology: molecular, biochemical, and cellular perspectives. Lewis Publishers, Boca Raton, pp. 87-206

472 Strange CJ. (2008) Troubling Waters. BioScience 58:1008-1013

473 Sundberg H, Ishaq R, Tjarnlund U, kerman G, Grunder K, Bandh C, Broman D, Balk L (2006)

474 Contribution of commonly analyzed polycyclic aromatic hydrocarbons (PAHs) to potential 475 toxicity in early life stages of rainbow trout (Oncorhynchus mykiss). Can J Fish Aquat Sci 63: $1320-1333$ 
Tanguay RL, Andreasen EA, Walker MK, Peterson RE (2005) Dioxin Toxicity and Aryl

Hydrocarbon Receptor Signaling in Fish. In: Dioxins and Health pp. 603-628. John Wiley \& Sons, Inc.

Tom M, Myers CR, Waterman MR (2002) Evaluating molar CYP1A level in fish hepatic microsomes by competitive ELISA using recombinant membrane-free CYP1A standard protein. Aquat Toxicol 59:101-114

Tom M, Auslander M (2005) Transcript and protein environmental biomarkers in fish: a review. Chemosphere 59:155-162

van der Oost R, Beyer J, Vermeulen NPE (2003) Fish bioaccumulation and biomarkers in environmental risk assessment: a review. Environ Toxicol Pharmacol 13:57-149

Viarengo A, Bettella E, Fabbri R, Burlando B, Lafaurie M (1997) Heavy metal inhibition of EROD activity in liver microsomes from the bass Dicentrarchus labrax exposed to organic xenobiotics: Role of GSH in the reduction of heavy metal effects. Mar Environ Res 44:1-11

Washburn BS, Vines CA, Baden DG, Hinton DE, Walsh PJ. (1996) Differential effects of brevetoxin and [beta]-naphthoflavone on xenobiotic metabolizing enzymes in striped bass (Morone saxatilis). Aquat Toxicol 35:1-10

Willett KL, McDonald SJ, Steinberg MA, Beatty KB, Kennicutt MC, Safe SH (1997) Biomarker sensitivity for polynuclear aromatic hydrocarbon contamination in two marine fish species collected in Galveston Bay, Texas. Environ Toxicol Chem 16:1472-1479

Willett KL, Wassenberg D, Lienesch L, Reichert W, Di Giulio RT (2001) In Vivo and in Vitro Inhibition of CYP1A-Dependent Activity in Fundulus heteroclitus by the Polynuclear Aromatic Hydrocarbon Fluoranthene. Toxicol Appl Pharmacol 177:264-271

Wills LP, Jung D, Koehrn K, Zhu S, Willett KL, Hinton DE, Di Giulio RT (2010) 
500 Comparative chronic liver toxicity of benzo[a]pyrene in two populations of the atlantic killifish

$501 \quad$ (Fundulus heteroclitus) with different exposure histories. Environ Health Perspect

$502 \quad 118: 1376-81$

503 Wirgin I, Konkle B, Pedersen M, Grunwald C, Williams J, Courtenay S (1996) A comparison of

$504 \quad$ cytochrome P4501A (CYP1A) mRNA inducibility in four species of Atlantic coast

$505 \quad$ anadromous fishes. Estuaries \& Coasts 19:913-922

506

507 
508 Table 1. Primer and Probes for Cypla (precisely CYP1A1) and $\beta$-actin used for quantitative PCR

509 assessments of gene expression in striped bass.

510

\begin{tabular}{|c|c|c|c|c|}
\hline Gene & $\begin{array}{c}\text { Species for } \\
\text { starting } \\
\text { sequence }\end{array}$ & $\begin{array}{c}\text { NCBI } \\
\text { GenBank } \\
\text { accession } \\
\text { number }\end{array}$ & Primer & Roche Probe \\
\hline \multirow{4}{*}{ Cypla } & Dicentrarchus & AJ251913 & Right: & \\
\hline & labrax & & GCGGCACAACCCCAGAGTA & No. 65; \\
\hline & & & Left: & CTGGAGGA \\
\hline & & & CAGCTTTCATGACGGTGTTGAG & \\
\hline \multirow{4}{*}{$\begin{array}{l}\beta- \\
\operatorname{actin}^{\mathrm{a}}\end{array}$} & Dicentrarchus & AJ493428 & Right: & \\
\hline & labrax & & GCAATGAGAGGTTCCGTTGC & No. 11; \\
\hline & & & Left: & CTTCCAGC \\
\hline & & & GCAGGACTCCATACCGAGGAA & \\
\hline
\end{tabular}

$512{ }^{a}$ reference gene

513

514

515

516

517 


\section{$518 \quad$ Figures captions}

520 Figure 1. Hepatic Cypla mRNA levels (A) and Cypla protein levels (B) in juvenile Morone

521 saxatilis, at $24 \mathrm{~h}$ following the injection of $0.1,1,10$ and $25 \mathrm{mg} \beta$-naphthoflavone. $\mathrm{Kg}^{-1}$. Values

522 represent means \pm SE. With sample size for the respective concentrations: $N=9,10,10,8$ and 9

523 (A); 10, 10, 10 and 10 (B). Significant differences from solvent control are indicated: * $p<0.05$;

$524 * * * p<0.01 ; * * * p<0.001$

526 Figure 2. Timed responses in hepatic Cypla mRNA (A) and protein levels (B) in juvenile Morone

527 saxatilis, following the injection with 0 (solvent control: SC) and $10 \mathrm{mg} \beta$-naphthoflavone. $\mathrm{Kg}^{-1}$

528 (BNF 10) at 0, 6, 12, 24, 48, 96 and 192 h. Values represent means \pm SE. With sample size for the

529 respective timed responses: $\mathrm{N}=9,8,8,8,10,4$ and 10 (A: $\mathrm{BNF} 10) ; 10,8,9,10,4$ and 10 (A:

$530 \mathrm{SC}) ; 9,8,10,10,10,4$ and 1010 (B: BNF 10); 10, 10, 9, 10, 4 and 10 (B: SC). Significant

531 differences from solvent control are indicated: * $p<0.05 ; * * p<0.01 ; * * * p<0.001$ 

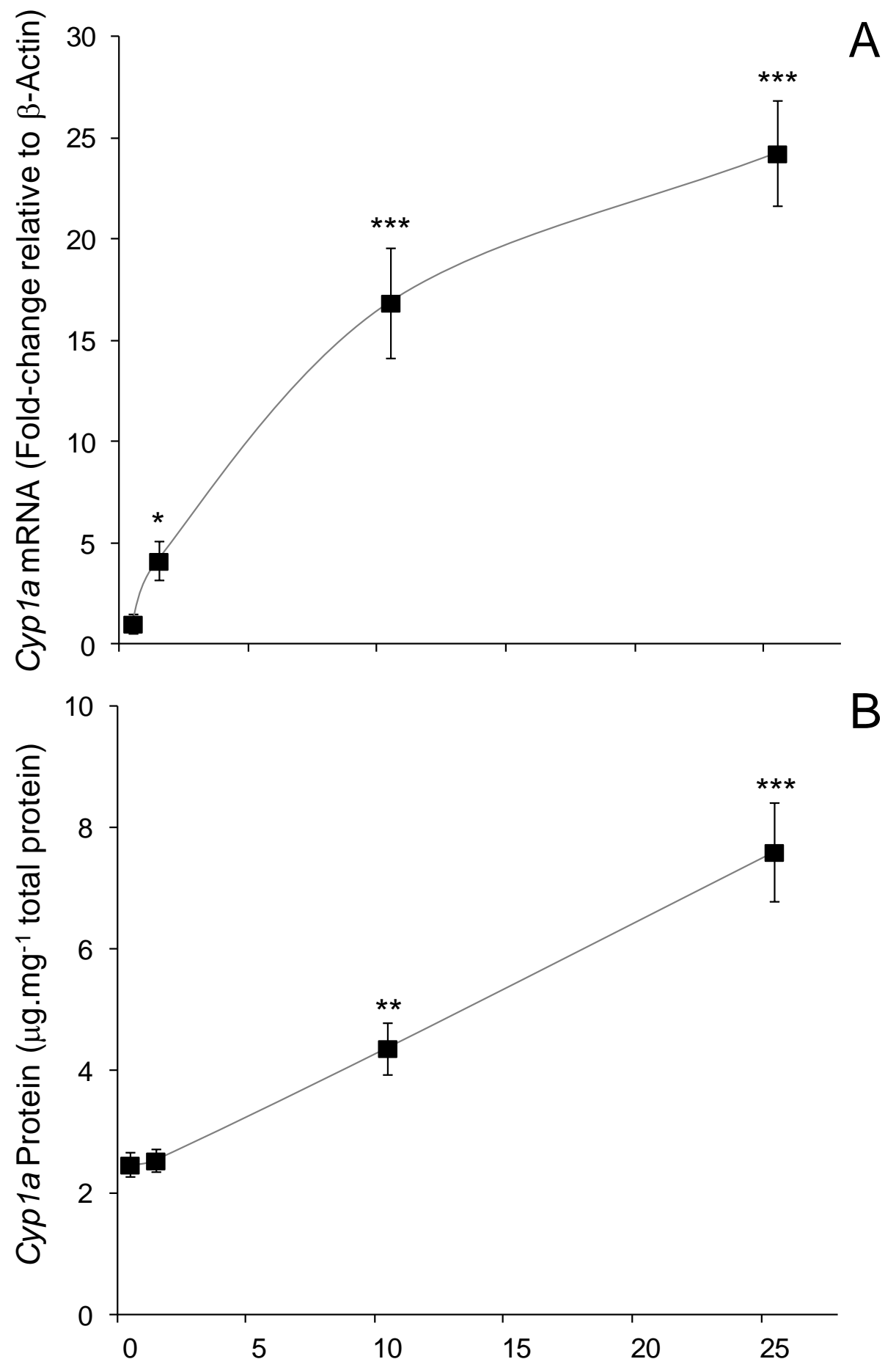

Dose (mg $\beta$-naphthoflavone. $\mathrm{Kg}^{-1}$ )

533 Fig. 1 

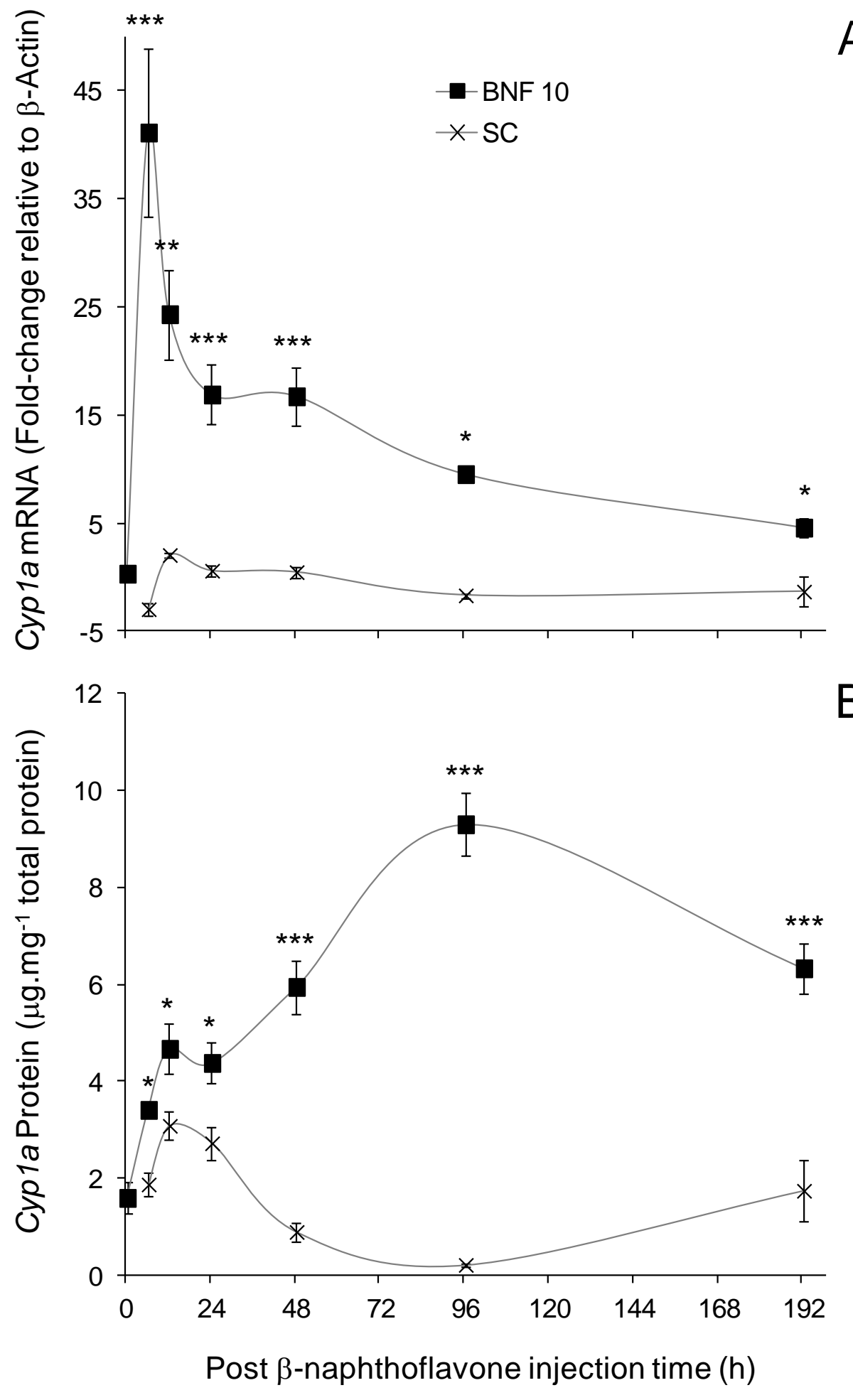

A

B

535 Fig. 2 